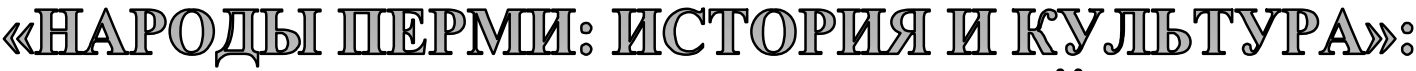

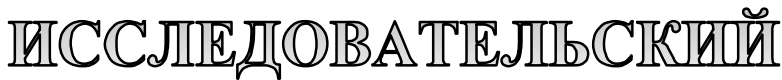

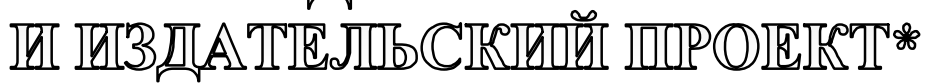

\author{
А.В. Черных, Пермский федеральный исследовательский центр УрО РАН \\ М.С. Каменских, Пермский федеральный исследовательский иентр УрО РАН
}

Представлен очерк реализации в 2015-2017 годах научно-популярного проекта «Народы Перми: история и культура», в рамках которого подготовлены издания об истории и современности в Перми русских, татар, марийцев, немцев, армян, грузин, башкир, коми-пермяков, евреев, корейцев, азербайджанцев, узбеков, украинцев, белорусов, удмуртов, поляков, таджиков и кыргызов. Раскрыты методология работы, методы сбора и анализа информации, представлено описание источниковой базы.

Ключевые слова: этническая история, Пермь, диаспоры, современное нащионально-культурное общественное движение, переписи населения.

Этнографические исследования, как правило, традиционно проводятся в сельской местности, где сохраняются места компактного проживания этнографических групп отдельных народов. Между тем в условиях современного информационного сообщества и урбанизации институциализация этнических сообществ активно происходит в городских условиях. Практически во всех крупных мегаполисах России имеются национально-культурные общественные институты, которые ведут деятельность по сохранению и популяризации своей культуры в условиях городской среды [15, с. 37]. На изучение этнических сообществ в условиях городской среды и был направлен научнопопулярный издательский проект «Народы Перми: история и культура». Его история началась в 2015 году, когда органы местного самоуправления были наделены полномочиями по обеспечению межнационального и межконфессионального согласия. Одним из направлений принятой в 2015 муниципальной программы «Укрепление межнационального межконфессионального согласия» г. Перми стала популяризация этнокультурного наследия [22].

Изначально проект планировалось реализовать силами общественных организаций, но по предложению Главы Перми Игоря Сапко было решено привлечь к работе этнологов и историков и подготовить издания не только популярные по форме, но соответствующие академическим стандартам. Проект был рассчитан на несколько лет.

Как правило, решение о включении в план проекта изучения того или иного этнического сообщества было связано с юбилейными или другими торжественны-

\footnotetext{
* Исследование выполнено в рамках реализации проекта № 18-6-6-4 «Межэтнические отношения в Прикамье: исторический опыт и современные практики» комплексной программы фундаментальных исследований УрО РАН.
} 
ми датами. В проект вошли издания как о традиционно проживающих в Перми народах, так о представителях т.н. «новых» этнических диаспор.

Редакционную коллегию проекта возглавил Глава Перми - Председатель Пермской городской Думы Игорь Сапко. В подготовке изданий принимали участие и представители национально-культурных центров, представляющих разные народы города Перми.

От научного сообщества к реализации проекта был привлечен научный коллектив сектора этнологических исследований отдела истории, археологии и этнографии Пермского научного центра УрО РАН. На тот момент коллектив уже имел опыт подготовки научных изданий как об отдельных народах Прикамья, так и о народах Пермского края в целом [19]. Между тем особенности проекта, его привязка к отдельной территории требовали проведения большого объема работ и внедрения новых методических подходов в региональной этнографии. В частности, была разработана универсальная структура для подобных изданий, включавшая в себя следующие разделы: «Этническая история» (происхождение народа согласно принятой в России академической традиции), «История народа в России, Прикамье и отдельно в Перми» (динамика численности данного народа согласно переписям населения, наиболее известные представители данного народа и их вклад в развитие города), «Язык» (описание языка данного народа, истории его возникновения и развития, литературы на данном языке), «Материальная и духовная культура» (традиционное жилище, костюм, кухня, религиозные традиции, особенности календарного цикла праздников и обрядов, семейные традиции), «Общественные организации и их деятельность» (возникновение в Перми общественной организации, ее роль в общественной жизни Перми на современном этапе).

В итоге в результате совместной работы органов местного самоуправления го- рода Перми, ученых и общественных организаций за 2015-2017 годы было издано 18 книг о разных народах города Перми.

К подготовке исследования был привлечен обширный корпус источников, работа с которыми позволила сконструировать универсальную методологию по реконструкции истории народа в рамках региона или города. Данная методология может быть использована в дальнейшем в других исследовательских проектах. В книгах систематизируются данные по всем переписям населения, начиная с 1897 и заканчивая 2010 годом, относящиеся к рассматриваемым народам. Использование материалов переписей позволяет не только проследить масштабы этнических миграций, но и составить социальный портрет определенных социальных групп. Так, анализ данных 1897 года позволяет выявить характеристики половозрастного состава, сфер деятельности, владения языками и религиозной принадлежности у отдельных групп народов [21, с. 92-95, c. 184-251]. Данные переписей 1926 [5, c. 106-107] и 1939 [6, с. 132-133] годов содержат сведения о численности городского и сельского населения, а также информацию о владении языками. Динамику развития этнической общности с точки зрения численности и сохранения языка, владения вторым языком позволяют выявить переписи 1959, 1970, 1979, 1989, [7] 2002 и 2010 годов [20;9].

Использование материалов переписей населения позволило реконструировать малоизученные фрагменты этнической истории народов, о которых почти ничего неизвестно. Важную роль в характеристике этнических общностей периода 1930-х годов сыграли судебно-следственные дела из фондов Пермского государственного архива социально-политической истории (ПермГАСПИ): в источниках представлены биографические сведения, данные о расселении и происхождении представителей разных народов.

В изучении современного этапа становления и развития этнических общностей большую роль сыграли архивы этни- 
ческих общественных объединений. Так, неоценимую помощь в написании книг оказали архивы «Русского национальнокультурного общества», «Общественного центра белорусов Пермского края», «Пермской региональной еврейской национально-культурной автономии», «Пермского центра польской культуры», «Пермского отделения Общества российских немцев «Видергебурт» («Возрождение») и др.

Еще одним важным источником послужили данные полевых исследований, особенно в работе с новыми этническими диаспорами. История народов Кавказа и Средней Азии в Перми начиналась, как правило, со второй половины XX века, в связи с чем опубликованная и архивная источниковая база не позволяет проводить полномасштабные исследования. Запись интервью, между тем, дает возможность восстановить этапы истории народа, особенности его менталитета, представлений и ценностей, сохранения традиций в инокультурной среде.

В целях более глубокого изучения современных этнических процессов среди некоторых народов в 2001-2013 годах были проведены также этносоциологические исследования по специально разработанным опросным листам (кыргызы, таджики, корейцы, чуваши). Некоторые основные итоги этих исследований, позволяющие дать представления об особенностях идентичности, степени владения родным и русским языками, также использовались при написании книг.

Среди опубликованных источников использованы данные периодической печати. В книгах представлены материалы газет «Пермские губернские ведомости», «Известия Пермского губернского исполнительного комитета совета рабочих и крестьянских депутатов», «Звезда», «Business-class», «Местное время», «Прикамье многонациональное», «Содружество»; журналов «Жизнь национальностей», «Народы Пермского края», «Пермский край - территория межнационального согласия», буклетов «Пермь великая -
Пермь многоликая», «Наш многоликий город Пермь» и др.

В 2015 году по предложению экспертов в план проекта были включены издания о русских, татарах, грузинах, армянах, немцах и марийцах.

Непросто было начинать проект с русских, которые составляют в Перми более $80 \%$ населения. Рассказ об истории русских в Перми мог бы «продублировать» описание истории города в целом. Между тем авторы смогли найти компромиссный вариант, позволивший показать на примере Перми особенности русской культуры в Прикамье, не превращая это в просто рассказ об истории города. В книге отражены особенности материальной и духовной культуры русских в Прикамье, участие различных групп русских в освоении региона и развитии города. Современное общественное движение представлено деятельностью ряда фольклорных коллективов, занимающихся популяризацией традиционной русской культуры. Книга «Русские Перми: история и культура» готовилась при участии «Русского национально-культурного общества» [17].

Татары, являющиеся вторым по численности народом города Перми, также были включены в план проекта на 2015 год. Большую роль в подготовке издания сыграли активисты Татарской национально-культурной автономии города Перми, а также администрация детского сада № 355 «Чулпан», где наряду культурами других народов России в образовательном процессе представлен этнокомпонент татарской культуры. В книге впервые описана история татарского купечества Перми начала XX века, опубликованы фотографии того периода. Авторский коллектив также смог значительно обогатить представления об истории татар в Перми, особенно второй половины XX века, когда в Прикамье был зафиксирован значительный приток татарского населения [29].

Сложной с точки зрения систематизации информации была работа над книгой 
по истории немцев. Большой вклад представителей этого народа в развитие Перми с момента основания города уже неоднократно отмечался в местной историографии. Перед авторами стояла непростая задача не только изложить историю немцев, но и сделать это в системе, в доступной форме, не забыв при этом упомянуть все важные этапы их истории. Существенную помощь при отборе материала научному коллективу оказывали активисты местной общественной организации российских немцев «Видергебурт» («Возрождение») в г. Перми [4].

Главная сложность работы над историей пермских марийцев заключалась в том, что исторически марийское население Прикамья формировалось в его юговосточных районах, а городское сообщество марийцев смогло оформиться лишь в последние два десятилетия. При этом история марийцев Прикамья уже неоднократно изучалась ранее. Между тем в книге о марийцах Перми впервые проанализирован приток марийского населения в город во второй половине XX века, объяснены причины и движущие силы этого процесса [26].

История армян Прикамья также ранее неоднократно изучалась, особенно в контексте вклада в развитие Прикамья династии Абамелек-Лазаревых. Однако в издании о пермских армянах удалось гармонично проследить формирование армянского сообщества именно в Перми, на примере отдельных биографий пермских армян показана уникальность культуры и трудовой этики этого народа, впервые оценен вклад отдельных армян в развитии города. В книге не только изложены основы армянской культуры, но показано, как эта культура реализуется в пермских условиях. Представлены, в частности, очерки о деятельности Армянской воскресной школы им. Месропа Маштоца и о коллективе армянского танца «Крунк», о строительстве Армянской церкви, об организации и проведении в Перми традиционных армянских праздников и др. Большую роль в пре- доставлении информации и подготовке отдельных разделов сыграли и активисты региональной общественной организации «Центр Армянской культуры Пермского края» [11].

К истории грузин не только в Перми, но и в Прикамье в целом ученые подошли впервые. Силами краевой общественной организации грузин «Иберия» была реконструирована и описана история грузинского народа в Перми, выявлена история «грузинского дома» на ул. 25 Октября, а также раскрыта масса интересных эпизодов из прошлого и современного развития грузинской общины. Как и в работе над книгой по истории армян, авторы ставили целью показать грузинскую культуру в контексте ее реализации в городе Перми: грузинская воскресная школа, рестораны грузинской кухни, грузинские ансамбли и др. [12]. Презентация книги «Грузины Перми: история и культура» прошла на юбилейном мероприятии организации «Иберия» по случаю 10 -летия с момента основания [23].

Первые шесть изданий проекта «Народы Перми: история и культура» были закончены согласно установленному плану. Тираж издания был распространен среди библиотек и учебных заведений города Перми, часть книг получили и общественные организации, принимавшие участие в их подготовке. Презентация изданий прошла в рамках заседания Совета по межнациональным и межконфессиональным отношениям при Главе города Перми в феврале 2016 года. Реализация проекта была оценена как успешная, в 2016 году редколлегией был утвержден новый список народов, включавший башкир, коми-пермяков, корейцев, евреев, узбеков и азербайджанцев.

Коми-пермяки - древний для Прикамья народ, компактно проживающий в северных районах Пермского края. Его история и современное этническое развитие активно изучались российскими и зарубежными учеными досоветского, советского и современного периодов. Между тем история коми-пермяков в городе Пер- 
ми пока не становилась предметом отдельного изучения. В книге впервые были представлены сведения об общественном коми-пермяцком движении в Перми в 1920-е годы, оценена роль открытия коми-пермяцко-русского отделения на филологическом факультете Пермского педагогического института в 1955 году. Отделение сыграло очень важную роль в создании инструментов для сохранения и популяризации уникальной культуры коми-пермяков не только в Коми-Пермяцком округе, но и на территории всего Прикамья. Впервые представлен очерк о создании и деятельности Общественного коми-пермяцкого центра в городе Перми, активисты которого принимали участие в создании книги [8].

История башкир Перми также впервые стала предметом интереса пермских историков. Авторским коллективом введен в научный большой массив документов о жизни пермских башкир в Перми в начале ХХ века и в 1920-1930-е годы, о формировании башкирской общины в городе Перми в 1970-е годы, а также о создании и деятельности на современном этапе Курултая башкир города Перми [25].

Большая работа проведена в рамках исследования истории пермских евреев. Евреи являются одним из традиционно проживающих и исторически давно сложившихся этнических сообществ города Перми. Активистами Пермской еврейской национально-культурной автономии накоплен большой объем документов, многие из которых до сих пор не введены в научный оборот. К сожалению, формат проекта и ограничения по объему не позволили представить историю евреев в Перми во всей полноте. Однако авторы пытались показать ее в контексте истории города, особенно в XX веке. В книге впервые были опубликованы биографии известных пермских деятелей еврейского происхождения из самых разных сфер общественной жизни, общественное национально-культурное движение евреев в Перми на современном этапе [2].
Книга по истории пермских корейцев готовилась в рамках юбилея Пермской корейской национально-культурной общественной организации «Бухаль» («Возрождение»), которая в начале 2017 года отметила 25-летие деятельности [1]. Однако работа в пермских архивах позволила значительно «удревнить» историю пермских корейцев. Так, в книге были представлены документы о Русской школе для корейцев при пермском КириллоМефодиевском училище 1904 года, о деятельности корейской секции при Пермском губкоме в 1920-е годы. Кроме этого, впервые описана история пермских корейцев в послевоенный период 19501960-х годов, представлены очерки биографий известных пермских корейцев, их вклад в развитие города [13].

Существенный вклад проект «Народы Перми: история и культура» позволил внести в изучение истории пермских азербайджанцев. Несмотря на большую роль выходцев из Азербайджана в развитии пермской нефтедобычи, их история пока не становилась предметом отдельных исследований. Долгая работа в архивах и музеях Прикамья, встречи со старожилами позволили по-новому взглянуть на историю азербайджанцев в Перми, на их вклад в развитии города, особенно в 1930-1940-е годы, когда Урал на официальном уровне называли «вторым Баку». В книге также впервые описана современная история азербайджанских общественных организаций, их участие в культурной жизни города [10].

Последней в 2016 году была подготовлена книга «Узбеки Перми: история и культура». Главная сложность работы над созданием первого труда по истории в Перми крупнейшего народа Средней Азии заключалась в том, что в разное время в Перми создавалось несколько общественных организаций узбеков, многие из которых существовали непродолжительный период. Однако точечная кропотливая работа с активистами нескольких общественных организаций позволила впервые комплексно представить историю уз- 
беков в Перми, описать культурные связи Перми и Узбекистана в досоветский и советский периоды, представить сохранение и развитие узбекской культуры в пермских условиях [3].

В 2017 году реализация проекта продолжилась подготовкой еще шести научных трудов по истории пермских удмуртов, белорусов, поляков и украинцев, кыргызов и таджиков.

Как известно, Буйские удмурты являются уникальной этнографической группой для Пермского края, которая сформировалась в XVII веке на территории современного Куединского района. История пермских удмуртов уже неоднократно изучалась в разных аспектах. В Перми удмурты также являются одним из крупнейших по численности этнических сообществ. Однако ввиду отсутствия общественной организации непосредственно в Перми, работа над книгой по истории пермских удмуртов оказалась одной из наиболее сложных. Между тем, авторы отыскали много новых страниц в истории удмуртов в Перми (например, деятельность вотской секции при губкоме в 1920-е годы), а ресурсами краевого Национально-культурного центра удмуртов Пермского края удалось представить развитие удмуртской культуры в Перми на современном этапе [30].

Если говорить об истории поляков, то их роль в истории и развитии города Перми сложно переоценить. Их история в Прикамье также неоднократно изучалась пермскими и зарубежными историками. В работе над изданием авторский коллектив сосредоточился на новых или малоизученных эпизодах в истории пермских поляков, касающихся их участия в Гражданской войне на Урале, а также жизни поляков в Перми в условиях советского послевоенного времени [27].

Белорусы и украинцы в Пермском крае также являются одними из наиболее многочисленных этнических образований, а история их появления в регионе весьма схожа, чем и была обусловлена подготовка книг по истории этих народов в течение одного 2017 года. В книгах по истории белорусов и украинцев в Перми представлены очерки по появлению этих народов на Урале в результате переселенческой политики российского (советского) государства в разные периоды XX века. В издании по истории пермских белорусов впервые введены в научный оборот данные об участии выходцев из Белорусской ССР в развитии калийной промышленности Прикамья в 1970-е годы. Помимо истории, авторы представили очерки о современном развитии украинской и белорусской культур в условиях города Перми $[16 ; 18]$.

Первая книга по истории пермских таджиков была написана еще в 2000 году. C тех пор таджики, как одна из наиболее многочисленных новых этнических диаспор Прикамья, неоднократно становились объектом внимания ученых. В книге «Таджики Перми: история и культура» представлены обновленные данные о современном состоянии таджикской диаспоры, процессах, которые в ней происходят [28].

Кроме этого, в рамках 10-летнего юбилея пермского «Союза кыргызстанцев» в 2017 году была издана и презентована книга по истории пермских кыргызов, которые на сегодняшний день являются самой динамично развивающейся диаспорой Пермского края. Их изучение давно представлялось местным ученым весьма актуальным. Кроме анализа современных процессов, характерных для кыргызской диаспоры, авторскому коллективу удалось найти документы о торговле пермских купцов с кыргызами в XVIII веке, о совместных научных проектах в горной промышленности Пермской области и Кыргызской ССР и др. [14].

В целом, реализация проекта «Народы Перми: история и культура» в 20152017 годах позволила по-новому взглянуть на историю и роль целого ряда народов в развитии Перми, ввести в научный оборот большое количество не публиковавшихся ранее документов. Работа над 18 книгами позволила авторскому кол- 
лективу сформировать универсальную методологическую базу для подобного рода этнолокальных исследований. Данная методика и структура исследования могут быть реализованы не только в Перми, но и на территории других городов Пермского края и соседних регионов.

Помимо научной составляющей, проект имеет важное значение с точки зрения достижения целей государственной национальной политики, в задачи которой входит популяризация среди населения России знаний об истории и культуре ее народов.

По итогам реализации проекта в 2017 году принято решение продолжить еще на год и издать еще 6 книг о разных народах Перми.

\section{Библиографический список}

1. В Перми отметили 25-летие Корейской Национально-культурной Региональной Общественной Организации Пермского края «Бухаль» [Электронный ресурс]. URL.: http://www.duma.perm.ru/press/news/2017/4/14020/ (дата обращения: 23.02.2018).

2. Вайман Д.И. Евреи Перми: история и культура. - СПб.: Маматов, 2016. - 64 с.

3. Вайман Д.И., Каменских М.С. Узбеки Перми: история и культура. - СПб.: Маматов, 2016. - 64 с.

4. Вайман Д.И., Черных А.В. Немцы Перми: история и культура. - СПб.: Маматов, 2016. - 64 с.

5. Всесоюзная перепись населения 1926 г. Т. IV. Вот. р-н, Ур. обл., Башк. АССР. Отдел I. - М.: Издание ЦСУ ССР, 1928. - 303 с.

6. Всесоюзная перепись населения СССР 1939: Уральский регион. - Екатеринбург, 2002. - 600 с.

7. Государственный архив Пермского края (ГАПК). Ф. р-493. Пермское областное статистическое управление. Оп. 19. Д. 19, 20, 21, 106.

8. Голева Т.Г., Черных А.В. Коми-пермяки Перми: история и культура. - СПб.: Маматов, 2016. - 64 с.

9. Итоги Всероссийской переписи населения 2010 [Электронный ресурс]: Пермьстат. URL.: http://permstat.gks.ru/ (дата обращения: 30.09.2017).

10. Каменских М.С. Азербайджанцы Перми: история и культура. - СПб.: Маматов, 2016. - 64 с.

11. Каменских М.С. Армяне Перми: история и культура. - СПб.: Маматов, 2015. - 64 с.

12. Каменских М.С. Грузины Перми: история и культура. - СПб.: Маматов, 2015. - 64 с.

13. Каменских М.С. Корейцы Перми: история и культура. - СПб.: Маматов, 2016. - 64 с.

14. Каменских М.С. Кыргызы Перми: история и культура. - СПб.: Маматов, 2017. - 64 с.

15. Каменских М.С. Центр гражданского единения в мегаполисе // Вопросы культурологии. - 2016. № 7. - С. 37-39.

16. Каменских М.С., Черных А.В. Белорусы Перми: история и культура. - СПб.: Маматов, 2017. - 64 с.

17. Каменских М.С., Черных А.В. Русские Перми: история и культура. - СПб.: Маматов, 2015. - 64 с.

18. Каменских М.С., Черных А.В. Украинцы Перми: история и культура. - СПб.: Маматов, 2017. - 64 с.

19. Народы Пермского края: этническая история и современное этнокультурное развитие. Словарьсправочник. - СПб.: Маматов, 2014. - 416 с.

20. Национальный состав населения Пермской области. Пермь: Пермьстат, 2005. - 141 с.

21. Первая всеобщая перепись населения Российской империи 1897 года. Вып. 29-32. Губернии: Орловская, Пензенская, Пермская, Подольская. - СПб., 1904. - Т. XVI. - 259 с.

22. Постановление администрации города Перми от 16.10.2014 г. № 728 «Об утверждении муниципальной программы «Укрепление межнационального и межконфессионального согласия в городе Перми [Электронный ресурс]: Электронный фонд правовой и нормативно-технической документации. URL.: http://docs.cntd.ru/document/428689264 (дата обращения: 21.02.2018).

23. Состоялся юбилей краевой общественной организации грузин «Иберия» [Электронный ресурс]: Народы Пермского края. URL.: http://etnoperm.ru/novosti/360-ubilei-iberia.html (дата обращения: 21.02.2018).

24. Федеральный закон от 22.10.2013 г. № 284-Ф3 О внесении изменений в отдельные законодательные акты Российской Федерации в части определения полномочий и ответственности органов государственной власти субъектов Российской Федерации, органов местного самоуправления и их должностных лиц в сфере межнациональных отношений [Электронный ресурс]: Консультант Плюс. URL.: http:/www.consultant.ru/document/cons_doc_LAW_153536/ (дата обращения: 21.02.2018).

25. Черных A.B. Башкиры Перми: история и культура. - СПб.: Маматов, 2016. - 64 с.

26. Черных A.B. Марийцы Перми: история и культура. - СПб.: Маматов, 2015. - 64 с.

27. Черных A.B. Поляки Перми: история и культура. - СПб.: Маматов, 2017. - 64 с.

28. Черных A.B. Таджики Перми: история и культура. - СПб.: Маматов, 2017. - 64 с.

29. Черных A.B. Татары Перми: история и культура. - СПб.: Маматов, 2015. - 64 с.

30. Черных A.B. Удмурты Перми: история и культура. - СПб.: Маматов, 2017. - 64 с. 


\title{
«ETHNIC MINORITIES OF PERM: HISTORY AND CULTURE»: A RESEARCH AND PUBLISHING PROJECT
}

\author{
A.V. Chernikh, M.S. Kamenskikh \\ Perm Federal Research Center UB RAS
}

The article presents an essay on the implementation in 2015-2017 of the popular-science project «Ethnic minorities of Perm: history and culture», in which editions about the history and the present in Perm of Russians, Tatars, Maris, Germans, Armenians, Georgians, Bashkirs, Komi- Permians, Jews, Koreans, Azerbaijanis, Uzbeks, Ukrainians, Byelorussians, Udmurts, Poles, Tajiks and Kyrgyz. The methodology of work, methods of information collection and analysis are disclosed, the description of the source database is provided.

Keywords: Ethnic history, Perm, diaspora, modern national-cultural societies, population censuses.

\section{Сведения об авторах}

Черных Александр Васильевич, доктор исторических наук, член-корреспондент РАН, заведующий сектором отдела истории, археологии и этнографии, Пермский федеральный исследовательский центр УрО РАН (ПФИЦ УрО РАН), 614900, г. Пермь, ул. Ленина, 13А; e-mail: atschernych@yandex.ru

Каменских Михаил Сергеевич, кандидат исторических наук, старший научный сотрудник отдела истории, археологии и этнографии, ПФИЦ УрО РАН; e-mail: pomidorrr@mail.ru 